\title{
Evaluation of Role of Heavy Metals in Causation of Colorectal Cancer
}

\author{
Snigdha Sarkar¹, Saibal Kr. Mukherjee ${ }^{2}$, Krishnangshu Roy³, Parthasarathi Ghosh4 \\ ${ }^{1}$ Department of General Surgery, Calcutta National Medical College, Kolkata, West Bengal, India. ${ }^{2}$ RRS \\ Medical College, Kolkata, West Bengal, India. ${ }^{3}$ Institute of Health and Family Welfare, Salt Lake, West Bengal, \\ India. ${ }^{4}$ Department of General Surgery, Diamond Harbour Government Medical College, Diamond Harbour, \\ West Bengal, India.
}

\section{ABSTRACT}

\section{BACKGROUND}

Over last two decades, there is increasing incidence and high prevalence of colorectal cancer in young Indians, who are mostly from rural environment with a very low socio-economic condition, consuming a diet low in meat, fat, but rich in carbohydrate and fiber with a normal or less than normal body weight. These facts have clearly indicated a completely separate epidemiological profile of this cancer in our country and so may be caused by some different and unknown etiological factors. West Bengal and Bangladesh (the Gangetic belt) are quite developed in agriculture and to some extent in industry as well. This implies a significant contamination of drinking water for this large population with industrial wastes containing heavy metals. As many of the heavy metals (lead, chromium, cadmium) have proved to be associated with gall bladder cancer in our country and heavy metal poisoning (arsenic) is common in this geographical region, we searched for the effect of some heavy metals in causation of colorectal cancer here.

\section{METHODS}

Our case-control study compared the tissue levels of two heavy metals namely arsenic and lead. In a city government hospital of Kolkata (eastern India), 50 sporadic colorectal cancer patients were compared with 100 age and sex matched benign colorectal cases over a period of one and half years. Quantitative estimation of arsenic and lead in colonic tissues by atomic absorption spectrophotometry was done to detect any significant difference between these two groups.

\section{RESULTS}

Our study did not find any statistically significant difference in the tissue levels of arsenic and lead between the cases and controls ( $p$ value $>0.05$ ).

\section{CONCLUSIONS}

Our study does not show any association of heavy metals with colorectal cancer, although this remains a possibility. We do not have any population-based reference data on levels of heavy metals in tissues of normal population in this geographic region, which made the comparison difficult.

\section{KEY WORDS}

Colorectal Cancer, Heavy Metals, Arsenic, Lead

\author{
Corresponding Author: \\ Parthasarathi Ghosh, \\ Flat No. 503, Maitri Apartments, \\ \#255, NSC Bose Road, \\ Kolkata-700047, West Bengal, India. \\ E-mail: parthasurg@gmail.com
}

DOI: $10.14260 /$ jemds/2020/223

Financial or Other Competing Interests: None.

How to Cite This Article:

Sarkar S, Mukherjee SK, Roy K, et al. Evaluation of role of heavy metals in causation of colorectal cancer. J. Evolution Med. Dent. Sci. 2020;9(13):1036-1039, DOI: $10.14260 /$ jemds/2020/223

Submission 25-01-2020,

Peer Review 07-03-2020,

Acceptance 12-03-2020,

Published 30-03-2020.
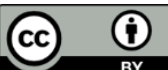


\section{BACKGROUND}

Colorectal cancer is the most common malignancy in the gastro-intestinal tract. Although the incidence of colorectal cancer had remained fairly constant or decreasing over the last two decades in the United States, its incidence has increased in the developing countries including India, probably due to westernization of diet and life-style. ${ }^{1}$ Study has revealed high prevalence of colorectal cancer in young Indians, who are mostly from rural environment with a very low socio- economic condition, consuming a diet low in meat, fat, but rich in carbohydrate and fiber with a normal or less than normal body weight. These facts have clearly indicated a completely separate epidemiological profile of this cancer in our country. ${ }^{2}$ The exact etiology of this cancer like many other cancers is not yet clear, leaving behind many facets which are still controversial. A number of genetic and environmental risk factors are considered to be associated with the disease. ${ }^{3}$ Although there are familial variety, most of the cancers are sporadic in nature (80\%). ${ }^{4}$ Such cases result after a sequence of genetic mutations influenced by environmental factors. ${ }^{5}$

Colon cancer rates have historically been among the lowest in Indians in contrary to the western world. In India colon cancer incidence in urban society is $3.7 / 3$ per $1,00,000$ males/ females respectively and that of rectal cancer is 3.9 / 2.7 (both are data from Bombay registry). ${ }^{3}$ This low incidence is attributed to high intake of starch, fibers as well as natural anti-oxidants (curcumin). ${ }^{1}$ But in the last few years incidence rate has increased ${ }^{6}$ a lot in Indian population (both men and women) along with an emergence of a totally different demographic and clinical variant among them ${ }^{7}$. As many of the heavy metals (lead, chromium, cadmium) have proved to be associated with gall bladder cancer ${ }^{3}$ in our country and heavy metal poisoning (arsenic) is common in this geographical region. ${ }^{8}$

Revolutionary studies from Banaras Hindu University, Varanasi, India $^{3}$ already have shown association of high concentration of heavy metals in bile with gall bladder carcinoma. This region of eastern UP and western Bihar lies downstream the river Ganges, which is the main source of water for all uses like drinking, irrigation etc. The river receives an extra high load of pollutants in terms of untreated domestic sewage, industrial and agricultural effluents. The various pollutants present in Ganges water are agricultural pesticides; heavy metals such as cadmium, chromium etc.; industrial effluents containing aromatic hydrocarbons and nitrosamines and chemicals such as nitrates and nitrites which are byproducts of domestic sewage. A case- control study on 96 patients (38 gall bladder carcinoma and 58 gall stone disease) was done from January 1995 to March 1996. Bile was collected by needle aspiration from GB of all patients, at the time of surgery for estimation of cadmium, chromium and lead concentrations. Using histochemical techniques however, they had found that metallothionine was $70 \%$ in patients with GB cancer and $25 \%$ in those with gall stones. They found that cadmium, chromium and lead concentrations were significantly higher in carcinoma GB than gall stones. ${ }^{9}$ This can be explained by the presence of dangerously high concentrations of these metals in drinking water in this part of India.

In India, indiscriminate use of pesticides leads to contamination of water of Ganges. Study of 60 patients of GB cancers showed biliary concentration of commonly used pesticides like benzene hexachloride and dichlorodiphenyl trichloroethane (DDT) were significantly higher in patients with gall bladder cancer than cholelithiasis. ${ }^{10}$ Similarly the aldrin and endosulfan concentration in bile were also higher in patients with carcinoma GB than those with cholelithiasis. As most of the heavy metals are excreted from our system through hepato-biliary system, thereby having a high chance to act in conjunction with bile on colonic mucosa as well as rectal mucosa. Colonic mucosa naturally absorbs bile which may be an unknown risk factor for colorectal cancer also. Hence the present study is an attempt to evaluate the association of heavy metals like arsenic and lead exposure in causation of colon cancer.

The pollution of drinking water e. g. from rivers and pools has been recognized to be associated with an increased risk of colorectal carcinoma in some epidemiological studies in Zhejiang province of China, which has a higher incidence of colorectal cancer than rest of the country. ${ }^{11}$ Trend was seen towards increasing incidence rates for colorectal cancer from drinking water sources of municipal, river ditch, mixed water to well water. The significant risk from well water could be seen for colon and rectal cancer. A study from university of Korea, Seoul investigated the relationship between agricultural pesticides and colorectal cancer incidence. ${ }^{12}$ Chlorpyrifos use showed significant exposure response trend for rectal cancer and Aldicard was associated with significantly increased risk of colon cancer.

The widespread use of pesticides in Egypt, the incidence of colorectal cancer in Egyptian children and young adults had led to US case reports in which pesticides have been connected with colorectal cancer. High levels and large interindividual variability of DDE, DDT, beta HCH \& HCB levels were found in most subjects specially from those from rural areas involved in farming and who were aged.13

\section{METHODS}

A case-control study (1:2) was conducted at the Department of Surgery, R. G. Kar Medical College and Hospital, Kolkata in collaboration with the Department of Clinical and Experimental Pharmacology, School of Tropical Medicine, Kolkata from January 2009 to June 2010 on 50 cases and 100 controls. Both malignant tissues from cases and nonmalignant tissues from controls were compared in respect to levels of arsenic and lead (quantitative assays). All patients who were admitted with clinicopathological diagnosis of colorectal carcinoma for elective or emergency procedure, irrespective of age and sex were included in the study. But cases of colorectal carcinoma having familial or hereditary background, familial adenomatous polyposis or other polyposis syndrome or inflammatory bowel disease were excluded from the study.

Patients with symptoms of lower gastrointestinal bleeding, obstruction, signs of local or distant invasion were studied. A form of histopathological diagnosis of the cancer tissue was obtained during pre- operative evaluation (colonoscopic/ per rectal biopsy) of patients or during therapeutic intervention (elective/ emergency surgery). On the other hand, the age and sex matched controls suffering 
from benign colorectal conditions like appendicitis, volvulus, tuberculosis etc. which needed surgery and removal of tissue for biopsy were chosen for the study. About 10-25 gms of diseased colorectal tissues were collected from pre or postoperative specimens (both cases and controls) and sent to the laboratory. Initially tissues were enzymatically digested and then measured for arsenic and lead concentration by the method of atomic absorption with the help atomic absorption spectrophotometer. (Perkin-Elmer- model Analyst 100) one by one. The tissue concentrations of lead and arsenic was expressed in ppm unit and estimated concentrations were compared by standard statistical methods.

\section{Ethical Considerations}

Ethical clearance was taken from hospital ethical committee before undertaking the research work. All patients (cases and controls) required signing an informed consent before entering in the study. All those patients who participated in the study received standard treatment according to the stage of the disease.

\section{Statistical Analysis}

As levels of lead and arsenic are continuous variable, chisquare test could not be applied. Hence the cases and controls are compared with the help of standard error of difference between two means and the P-value estimated by unpaired $\mathrm{T}$ test. As levels of lead and arsenic are continuous variable, the cases and controls are compared with the help of standard error of difference between two means and the $p$-value estimated by unpaired $\mathrm{T}$ test.

\section{RESULTS}

In our study population prevalence of colorectal cancer was seen to gradually increase from a very young age group (youngest patient aged 14 years) to attain a peak of $44 \%$ in between 41-50 years and the gradually declined. Again, a smaller second peak was observed above 61 years. Male and female were equally (1:1) affected. Majority of our patients were from rural areas (70\%) and belongs to low income group (64\%). All of them used to consume average Indian non-vegetarian diet containing cereal, pulses, vegetables and small amount of fish and meat. Most of them (62\%) use ground water as drinking water and in $30 \%$ the source is surface water. Only one patient had BMI $>25$.

All the p-values are not statistically significant. This means null hypothesis is accepted and there is no statistical difference between cases and controls.

\begin{tabular}{|ccccc|}
\hline & $\begin{array}{c}\text { Mean } \pm \text { SD } \\
\text { Case }\end{array}$ & t- Value & p Value & Inference \\
$\begin{array}{c}\text { Tissue arsenic levels } \\
\text { of cases and controls }\end{array}$ & $\begin{array}{c}\text { arsenic }=0.144 \pm 0.185 \\
\text { Control arsenic } \\
0.130 \pm 0.073\end{array}$ & 0.208 & $>0.05$ & Not significant \\
$\begin{array}{c}\text { Tissue lead levels of } \\
\text { cases and controls }\end{array}$ & $\begin{array}{c}\text { Control lead } 1.82 \pm 0.839 \\
\text { Table 1. Results of Statistical Analysis }\end{array}$ & \\
\hline \multicolumn{5}{r}{ Tablificant } \\
\hline
\end{tabular}

\section{DISCUSSION}

An age impact on colorectal cancer incidence is greater than any other demographic factor. Sporadic colorectal cancer increases dramatically above the age of 50 years for all groups. ${ }^{14}$ Our study population showed a bimodal peak with highest number of cases in the age group of 41-50 years. ${ }^{3}$ Worldwide it has been observed that colorectal carcinoma is related to diet containing high animal fat and low fiber, obesity and sedentary lifestyle. But our population is mainly from low socioeconomic strata, rural region, non-obese and used to consume average Indian non-vegetarian diet containing cereal, pulses, vegetables and small amount of animal protein.

In India, there is a wide variation in the incidence of carcinoma gallbladder which is highest in eastern UP and western Bihar region. This wide demographic variation in incidence suggests that environmental factors might play an important role in its causation. This region lies downstream the river Ganges which is the main source of water for all uses like drinking, irrigation etc. The river Ganges receives an extra high load of pollutants in terms of domestic sewage, industrial and agricultural effluents. Heavy metals which are known potential carcinogen for lung, paranasal sinus and gastro-intestinal tract are also important causative agent for gall bladder cancer.

The study by V. K. Shukla et al. from Benaras Hindu University found that cadmium, chromium and lead concentrations in bile were significantly higher in carcinoma gall bladder patients than gall stone cases. At present there is no accepted model of experimental GB carcinogenesis. When such a link will be established the incidence of GB cancer can be brought down by instituting primary preventing measuring such as purification or decontamination of the drinking water and irrigation of well.

Increasing incidence of sporadic colorectal carcinoma specially in the young, non-obese hard-working Indians of eastern India in the recent years, may have some unknown environmental factors acting as carcinogens. Our study population is also coming from the same Gangetic belt consuming contaminated drinking water and are exposed to the same heavy metals like lead, arsenic.

Arsenic, an independent carcinogen, is widely present in the drinking well water of West Bengal and Bangladesh. This metal is already a proved causative agent for skin, lung, liver, urinary bladder, prostate and kidney cancers in this belt. Although the relationship between arsenic and colorectal cancer have not been searched in any of the studies earlier, our present study tried to find any hidden relationship between this two. To make the estimation process easier we have chosen only two heavy metals; one is lead (source: river Ganges) another is arsenic (source: well water) and estimated their quantitative presence in the colorectal tissues. The concentrations present in benign and malignant tissues were compared to detect any rise in the malignant ones. Our study revealed that the concentrations available were same in both benign and malignant tissues. Hence any association of lead and arsenic in causation of colorectal cancer cannot be proved by the present study. 


\section{CONCLUSIONS}

Our study does not show any association of heavy metals with colorectal cancer, although this remains a possibility. We do not have any population-based reference data on levels of heavy metals in tissues of normal population in this geographic region, which made the comparison difficult.

\section{ACKNOWLEDGEMENT}

We are very much thankful to Dr. Ashok Nandi and Dr. Shankar Poddar for doing all the laboratory tests and estimations of heavy metal concentrations at School of Tropical Medicine.

\section{REFERENCES}

[1] Mohandas KM, Desai DC. Epidemiology of digestive tract cancers in India. V. Large and small bowel. Indian J of Gastroenterology 1999;18 (3):118-21.

[2] Pal M. Proportionate increase in incidence of colorectal cancer at an age below 40 years: an observation. J Cancer Res Ther 2006;2 (3):97-9.

[3] Fry RD, Mahmoud N, Maron DJ, et al. Colon \& Rectum. In: Townsend CM, Beauchamp RD, Evers BM, et al. eds. Sabiston Textbook of Surgery. 18 ${ }^{\text {th }}$ edn. New Delhi: Saunders 2007: p. 1392.

[4] Bullard KM, Rothenberger DA. Colon, Rectum and Anus. In: Brunicardi FC, Anderson DK, Billiar TR, et al. eds. Schwartz's Principle of surgery. $8^{\text {th }}$ edn. New York: The McGraw-Hill Companies. 2007: p.1084.
[5] Carlson G, Epstein J. The small and large intestines. In: Williams NS, Bulstrode CJK, O'Connell PR, eds. Bailey \& Love's Short practice of surgery. 26 th edn. Boca Raton: CRC Press 2013: p. 1143-80.

[6] Pourhoseingholi MA. Increased burden of colorectal cancer in Asia. World J Gastrointest Oncol 2012;4 (4):6870.

[7] Sarkar S, Mukherjee R, Paira SK, et al. Profile of colorectal cancer in Eastern India. J Indian Medical Association 2012;110 (12):901-3.

[8] Hu H. Heavy metal poisoning. In: Braunwald E, Fauci AS, Kasper DL, et al. Harrison's Principles of Internal Medicine. 15th edn. New York: McGraw-Hill 2001: p. 2595.

[9] Shukla VK, Prakash A, Tripathi BD, et al. Biliary heavy metal concentrations in carcinoma of the gallbladder: case - control study. Br Med J 1998;317 (7168):1288-9.

[10] Shukla VK, Rastogi AN, Adukia TK, et al. Organochlorine pesticides in carcinoma of the gall bladder: a casecontrol study. Eur J Cancer Prev 2001;10 (2):153-6.

[11] Kun C, Weiping Y, Xinyan M, et al. The association between drinking water source and colorectal cancer incidence in Jiashan County of China. A prospective cohort study. The European J of Public Health 2005;15 (6):652-6.

[12] Lee JW, Sandler DP, Blair A, et al. Pesticide use \& colorectal cancer risk in Agricultural health study. Int J Cancer 2007;121 (2):339-46.

[13] Soliman AS, Smith MA, Cooper SP, et al. Serum organochlorine pesticide levels in patients with colorectal cancer in Egypt. Arch Environ Health 1997;52 (6):409-15.

[14] Libutti SK, Saltz LB, Tepper JE. Colon cancer. In: DeVita VT, Lawrence TS, Rosenberg SA, eds. Devita, Hellman \& Rosenberg's Cancer: Principals \& practice of oncology. $11^{\text {th }}$ edn. Philadelphia: Wolters \& Kluwer 2018: p. 91861. 